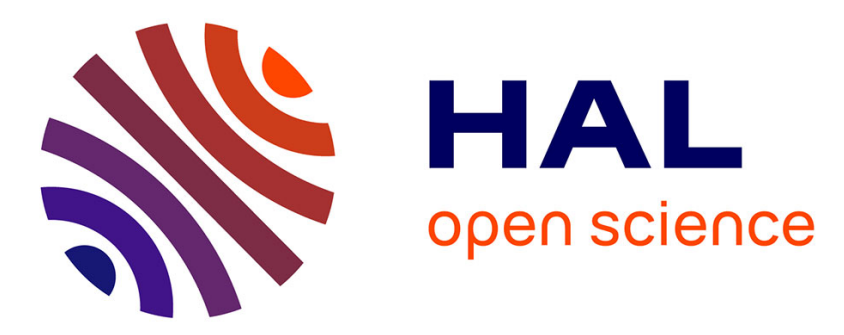

\title{
Why the ergative case in modal (in)transitive clauses? The historical evolution of Aspect, modality, ergative and locative in Indo-Aryan
}

Annie Montaut

\section{- To cite this version:}

Annie Montaut. Why the ergative case in modal (in)transitive clauses? The historical evolution of Aspect, modality, ergative and locative in Indo-Aryan. Dahl, Eystein \& Stronski, Krysztof. Indo-Aryan Ergativity in Typological and Diachronic Perspective, 112, Benjamins, pp.135-167, 2016, Typological Studies in Language, 9789027267160. hal-01313090

\section{HAL Id: hal-01313090 \\ https://hal.science/hal-01313090}

Submitted on 9 May 2016

HAL is a multi-disciplinary open access archive for the deposit and dissemination of scientific research documents, whether they are published or not. The documents may come from teaching and research institutions in France or abroad, or from public or private research centers.
L'archive ouverte pluridisciplinaire HAL, est destinée au dépôt et à la diffusion de documents scientifiques de niveau recherche, publiés ou non, émanant des établissements d'enseignement et de recherche français ou étrangers, des laboratoires publics ou privés. 


\section{Why the ergative case in modal (in)transitive clauses? The historical evolution of Aspect, modality, ergative and locative in Indo-Aryan}

Annie MONTAUT

Inalco, Paris, UMR 8202 (CNRS/INALCO/IRD). Program 'Investissements d'avenir' of the Agence Nationale de la Recherche ANR-10-LABX 0083 (Labex EFL)

annie.montaut@inalco.fr

In Ergativity in Indo-Aryan. Eystein DAHL \& Krysztof Stronski (eds). Benjamins

Abstract

Hindi transitive verbs, contrary to Bengali verbs, require the ergative structure in the perfective aspect, an atypical feature for an Indo-European language, and considered to display only surface ergativity, since most syntactic and discursive properties are attached to the agent. However its affinities with other locational predications in the dative, as well as the historical parallel rise of both pre-ergative and modal future patterns in Western Indo-Aryan, The paper develops Montaut's earlier suggestions $(1996,2006)$, with an attempt to reconcile Benveniste's well-known theory of the "possessive perfect" (1952) with Kurylowicz's views on the parallel evolution of future and past in Romance and Persian languages (1960), and a study of ergative and dative new markers in various Indo-Aryan languages.

Key words: Hindi ergative, modal future, possessive perfect, dative alignment

\section{Introduction}

It is well known that Hindi transitive verbs today, contrary to Bengali verbs, require the ergative structure in the definite past and related tense/aspects (perfect, pluperfect), a supposedly atypical feature for a modern Indo-European language. This alignment was long assumed to be only surface ergativity, since syntactic and discursive properties are attached to the marked agent which behaves as a pivot as well as a subject if we adopt Dixon's distinction, whereas in 'truly' ergative languages, the patient behaves as a pivot. In Modern Standard Hindi (MSH) indeed, the ergative agent displays more 'subject' properties than all other non canonical subjects. For example, not only does it control reflexivation (1a) and converb reduction whatever the sequential order (usne "he", the ergative agent of main verb dekhe "saw" provides by coreference the omitted subject of the converb daurāa.kar in (1b) although it occurs after), but it also undergoes converb reduction (daurāa.kar is the converb corresponding to the finite form in (1a) daura $\bar{a} . \bar{\imath}$ ), in contrast to other non-nominative subjects, which control but do not undergo converb reduction. It also always behaves as the main argument in chaining, particularly in coordination (2) ${ }^{1}$.

(1) a usne apne piche nazar daurāa.

(HINDI)

3SG.ERG REFL behind eye.F.SG run.CAUS.F.SG

'He looked around behind himself'

(1) bapne pīche nazar daurā.kar usne ve hì kapre dekhe jo... REFL behind eye run.CAUS.CV 3SG.ERG these FOC cloth.M.SG see.M.SG REL

'Looking around behind himself, he saw the very clothes that...'

\footnotetext{
${ }^{1}$ For more details on the distinctive S properties of ergative and other obliques, see my paper on the rise of noncanonical subjects (to appear).
} 
(2) billīne cū̄o pakrī aur kūdne lagī

cat.F.SGERG mouse.F.SG catch.F.SG and jump start.F.SG

'The cat caught the mouse and it (the cat/*the mouse) started to jump'

However, since it was noticed that topic continuity shows some difference between nominative and ergative subjects (Kachru 1987), it is now generally assumed that IA ergativity is not a simple surface anachronism. It has been extensively studied since the 80ies, mainly from a synchronic point of view (Davidson 2006, Mahajan 1997). A thorough inquiry about its emergence and development in NIA needs further investigation, after Peterson's study (1998), focused on Pali. Such investigation will help to test the idea that ergativity is a mirror image of transitivity, as argued by Dixon (1994). The paper, focused on Hindi within the wider picture of other IA languages, is an attempt in this direction. It elaborates the hypothesis already proposed in Montaut (1996, 2007): in IA a "pre-ergative" alignment first developed along lines similar to other ancient Indo-European languages, both in the past system (first section) and the modal future system, for both transitive and intransitive verbs (second section). The third section, dealing with the genesis of the new ergative case markers, originally locatives, provides further arguments for questioning the association between ergative with agent and source, and similarly the case alternations today observable between dative and ergative for certain modal sentences in the Western group of languages (section 4).

\section{Ergative alignments in Indo-Aryan: the passive verbal adjective as a predication of location}

\section{1. "Pre-ergative" alignments in Indo-Aryan:}

All the historians of NIA since Kellogg (1875) and Grierson (1903) mention that ergativity is a further development of the particular type of nominal sentence in Sanskrit with a past passive participle as the predicate, which came to replace the Vedic synthetic forms marked with tense and person (Cardona 1970, Pirejko 1979, Trask 1979):

\section{(3) mayā / mama tat krtam (SK) \\ 1SG.INS / 1SG.GEN DEM NOM.N.SG do.PPP.NOM.N.SG \\ 'I did/have done that (lit. 'by me/ of me this done')'}

In his study of nominal sentence in Sanskrit, Bloch (1906: 60) notices that the generalization of this nominal sentence is almost complete in Classical Sanskrit since the Vetâla stories display 1115 nominal forms against only 38 tensed forms in the expression of anterior events. Modern ergativity such as in (1) is clearly an inheritance from (3), with the phonological erosion of the -ita ending into -iya and $-a$. The morphology of the predicate in MSH and most Hindi dialects is still a nominal form, varying only in gender and number, which prompted Kellogg to make it a "participle tense" in 1856 as opposed to tensed forms (his "radical tenses"), and Grierson to make it a crucial criterium for his concentric classification, with Hindi in the central nucleus of IA because of the absence of person agreement for verbs in the "past" (Montaut 2007).

Although today Bengali and other Eastern languages ignore ergativity, such alignments for the past, are found from the West to East up to the $14^{\text {th }}-15^{\text {th }}$ century, from the early Prakrits as illustrated by Ashoka's first Edict (4, from Bloch's edition) both in Girnar (present Pakistan: Western) and Jaugada (Magadha kingdom around present Calcutta: Eastern), to the middle Prakrits as found in Kalidasa's Vikramorvasya in the $4^{\text {th }}$ century AC (5): 
(4) a. iyam dhammalip̄ devānampriyena priyadassina ranna lekhapita

(4) b. iyam dhammalipi devānampiyena piyadassina [lajina] lekhita

this law-scripture of-gods-friend friendly-looking king inscribed

NOM.F.SG NOM.F.SG INST.M.SG INST.M.SG INST.M.SG NOM.F.SG

'The friendly looking king beloved of gods has (made) engraved this law-edict' (PRK)

(5) hau pai pucchimi ... dițthī pia pai sāmuha jantī

1SG.NOM2.OBL ask.PRS.1SG seen.F.SGloved.F.SG 2.OBL in.front passing.NOM.F.SG

'I ask you... Did you see (my) beloved passing in front (of you)?' ${ }^{2}$ (PRK)

Right from this stage, a number of subject properties are attached to the agent despite its position (Hock 1992). In early NIA, the agent is systematically in the first position when expressed. The contrast displayed in (5), with nominative pronoun controlling intransitive verb agreement $v s$ oblique pronoun with transitive verbs, is still observable in $15^{\text {th }}$ century Awadhi where the intransitive hau manus "I [am] a man" contrasts with the transitive maï pāi "I obtained" (Tiwari 1966: 158). Throughout early NIA, agents have the oblique form (cf. 3.1) and verbs agrees with the patient, since gender and number are not yet totally lost in the Eastern languages and display the same construction as (4), which I will call pre-ergative. Ergative alignment is today confined to Western languages, but Old Bengali (6), Old Awadhi (7), derived from the Magadhean Eastern Prakrits, still presented the same pre-ergative structure as the mixed language of the saint poets or sant basha (8) and as Western languages derived from Saurasenic Prakrits, like Old Braj (9), Old Panjabi (10a) and Old Marathi (10b). The only difference is the presence of a "pleonastic" - $l$-after the verbal base in the East:

(6) a. kona puraṇe, kanhā, hena sunili kāhini (OLD BENGALI) which purana.LOC Krishna so heared.F.SG story.F.SG

'In which Purana, Krishna, did (you/one) hear this story? /was the story told?'

(6) b. ebẽ maï bujhila

(OLD BENGALI)

now 1SG.OBL understood-ø

'Now I have understood'

(7) a. taba lagi rānī suā chapāvā (OLD AWADHI: Jayasi, 89)

then up.to queen.F.SG parrot.M.SG hide.CAUS.M.SG

'Till the queen concealed the parrot'

(7) b. kāminni kone garhalī

(OLD AWADHI: Vidyapati 21)

woman.F.SG who.INS create.l.F.SG

'Who created this woman/by whom was this woman created'

(8) a. in karan kāliy $\tilde{\bar{a}}$ nathyã (SANT BHASHA: Mira 1)

DEM.MP sacred.feet.MP Kalya.snake.M.SG tame.M.SG

'These sacred feet tamed the serpent Kalya'

(8) b. māi re mha liyã govidã mol (SANT BASHA: Mira 19)

sister hey 1S.INS take.M.SG Govinda.M.SGpay

'Sister, I have bought Govinda (the god Krisna) in the market'

(9) cāri padārath diye sudāmahi

four product.M.PL give.M.PL Sudama.DAT

'[You] gave the four fruits of life to Sudama' (OLD BRAJ: Surdas 135)

\footnotetext{
${ }^{2}$ The form pai for $2^{\text {nd }}$ person is already used as a syncretic marker for several oblique cases.
} 
(10)

a. guri dānu ditta

guru.LOC gift.M.SG given.M.SG

(10)
(OLD PUNJABI: Guru Granth Sahib)

'The guru gave the gift'

(OLD MARATHI: Jnanesvari)

'I have seen this'

There is little doubt about the passive morphology of the predicate in Sanskrit, as well as the marking of the agent, although the past passive participle had of course a resultant meaning: instrumental was the regular marker of passive agents, and the optional genitive (for pronouns) did not survive in NIA such as Hindi, where the present form main for the first person pronoun is directly derived from the Sk instrumental mayā. Speijer (1886 [1980]: 3-4, §7), when noting that "Sanskrit has a definite predilection for the passive voice", where "the agent is invariably put in the instrumental", quotes examples of type (3) along with finite statements. But as soon as the participle started grammaticizing as the only expression for past, it assumed both a stative / resultative meaning (perfect) and an anterior meaning, what Nespital (1989) identified as a "Proto-Aktiv Satz" right from the Pali stage in Milindapanna. This change in meaning has been well documented in Peterson (1998:190) for Pali and Breunis (1990) for classical Sanskrit. I have accounted for this shift Montaut (1999) on the lines of Bybee, Perkins \& Pagliuca (1994) within the general process of grammaticalisation of the new periphrastic form.sg: as long as the nominal form, initially a marked innovation, competed with the old tensed forms, it retained its original restricted meaning (stative). When the old forms disappeared, the new form, no longer contrasting, occupied the whole space of past and acquired an open meaning, no longer marked (preterit or anterior, resultant, stativeresultant and stative). When a copula came into use, first in order to prevent ambiguities when overt pronouns in the first two persons were omitted (Bloch 1906), then to signal a restricted meaning stative-resultant as an expression of stylistic emphasis (Breunis 1990:141), the simple form started to contrast with the new copula one as the unmarked form with the marked one, and restricted its meaning to what was not expressed by the copula form: anterior event, namely a preterit ${ }^{3}$.

This aspectual feature has been responsible for the particular syntax which developed not only in Indo-Aryan, but in other ancient IE languages which also displayed a similar renewal of the perfect. This major shift in alignment was studied in a brilliant way by Benveniste 1952 and Kurylowicz $(1931,1965)$ with their further developments in modern romance languages.

\subsection{Benveniste's theory of the possessive meaning of perfect}

The classical assumptions about the passive to active shift of such constructions as (3) were renewed in the early fifties by Benveniste's polemical claim about the nature of perfect. In a very famous paper in 1952, he established that the original meaning of the periphrastic perfects in Late Latin and old Indo-Iranian, which renewed the synthetic forms of classical Latin and Vedic or Avestic past tense in the same way as (3), was basically not passive but possessive, on the basis of a comparison between Latin and Avestic such as:
(11) mihi id
factum (est)
(LATIN)
1SG.DAT DEM NOM.N.SG
do.PPP.NOM.N.SG (be.PRS.3s)

\footnotetext{
${ }^{3}$ Bubenik \& Paranjape 1996 (116-7) suggests that the placing of the agent in the first position in late MIA correlates with the linguistic perception of the oblique noun as a semantic subject. Breunis (1990) in his chapter on word order (6) suggests that the fronting of the agent is earlier, which is confirmed by many of the examples from Bloch (1906). The fronting of the marked agent amounts to treat it as a topic, which is a first step on the way to shifting it to the subject status, yet topicalization may remain distinct from grammatical properties (Falk 2006).
} 
'I did/have done that' (lit. 'by me/ of me this done')
(12) mana tya
krtam
(OLD IRANIAN)
1SG.GEN DEM NOM.N.SG do.PPP.NOM.N.SG
'I did/have done that' (lit. 'of me this done') cf. Sk (3), Prakrit (4)

The classical view on this evolution as illustrated for instance in Kurylowicz, on similar examples, was that these patterns were passive, and became active only when restructured with the 'have' auxiliary and nominative subject in Later Latin and Romance languages as French, Spanish or Italian:
(13) ego
id
factum
habeo
(LATIN)
1SG.NOM DEM NOM.N.SG do.PPP.NOM.N.SG have.PRS.1SG
'I have done that/it' (lit. I have this done)
(14) j'ai fait ceci (FR) io ho fatto questo (IT) yo he hecho esto (SP)

(ROMANCE LG)

"In the evolution that we consider, says Kurylowicz (1931: 107), the decisive step is in the replacement of the dative + esse [be] + nominative by nominative + habere [have] + accusative. The passive construction has been transformed into an active one".

Benveniste in contrast, as a specialist of Iranian languages, makes a strong argument of the case marker in order to dismiss the passive interpretation of perfects: the agent is in the genitive in Iranian, a case also used for possessors, in possessive. The argument is that in Latin the possessive case (dative) is used for both possessors and agents in the perfect, and that in Iranian as well as in Latin, this case is distinct from the instrumental required for passive agents, respectively hacama and $a \mathrm{me}$ ). Hence the term of "possessive" meaning chosen by Benveniste to rename the meaning of the Indo-European perfect. He argues that the so-called shift from passive to active was in fact the renewal of a past tense by a stative expression. A similar conclusion was reached by Pirejko (1979) and Trask (1979: 397) who assigns the possessive origin to the "incorporation into the inflectional paradigm of a nominal form" with a genitive (agentive) complement.

Another further-reaching argument Benveniste develops is that both possessive statements and periphrastic perfects came to be restructured in Latin with have and nominative subject around the same period, in the first centuries AD. A new periphrastic expression appeared, with the agent in the nominative controlling the agreement of the verb "have" which replaced to the old "be", and this new expression got generalized in all romance languages, which form their perfect with the (now) auxiliary 'have', the same verb they use for possession:
(15) mihi est filius /
pecunia
(CLASSICAL LATIN)
1SG.DAT be.3SG son.NOM.M.SG/ money.NOM.F.SG
'I have a son/ money'
(16) ego filium/ pecuniam habeo
1SG.NOM son.M.SG.ACC/money.F.SG.ACC have.1SG
$\begin{array}{ll}\text { (17) } j^{\prime} & \text { ai un fils / de l' argent } \\ 1 \mathrm{SG} \text { have a son ARTICLE money }\end{array}$
(LATE LATIN)
(FRENCH)

The point made by Benveniste against a passive reading of perfects is however not restricted to the case marking, which would not account for the OIA data, since instrumental is quite

\footnotetext{
${ }^{4}$ The French peculiarity of the double agreement with preposed object (the auxiliary 'have' agrees with subject, while the participle of main verb agrees with the object: je l'ai vu [1s 3MS have.1s seen.MS] vs je les ai vues (1s $3 \mathrm{FP}$ have.1S seen.FP) is clearly a remnant of the old perception of the 'possessive' periphrastic perfect.
} 
usual (Speijer 1886: 4) and points towards a passive agent rather than a possessor. The gist of his theory relies on the relation between perfect and stative predications, beyond the possessive statements in (15): in Romance languages, 'have', which Benveniste elsewhere (1966 [1952]) considers as a stative rather than a possessive verb, is also used for many of the non active predicates (physiological and psychological predicates such as 'be cold/hungry/happy', etc.). According to him, 'have' both as an auxiliary for tense/aspect and as a verb, is simply an 'inversion' or 'reversion' of "be" verb. By defining "have" as an "inverted be", Benveniste refers to its semantics, which is not active but basically stative and then equivalent to 'be', and to its argument structure, with subject in the nominative and object in the accusative, in contrast ("inversion") to "be" with both NPs respectively in the dative and nominative. "Avoir is nothing else than a "be-to" inverted (mihi est pecunia = habeo pecuniam). The nominative is not an agent but the localizer of a state, ${ }^{5}$ seemingly transitive but in reality intransitive and stative". Similarly avoir "have" is semantically intransitive/stative when used as auxiliary for perfect "I have done" (Benveniste 1960: 197).

TABLE 1 innovations in IE perfect and possessive clauses

\begin{tabular}{|l|l|l|l|}
\hline change 1 & Marked agent & Unmarked patient & Verb agr: P \\
\hline OIA & $\begin{array}{l}\text { mayā } \text { INS } \\
\text { mama } \text { GEN }\end{array}$ & tat NOM.N.SG & $\begin{array}{l}\text { krtam } \\
\text { PPP.NOM.N.SG }\end{array}$ \\
\hline OPe & mana GEN & tya NOM.N.SG & $\begin{array}{l}\text { kartam } \\
\text { PPP.NOM.N.SG }\end{array}$ \\
\hline Latin & mihi DAT & id NOM.N.SG & $\begin{array}{l}\text { factum (est) } \\
\text { PPP.NOM.N.SG (is) }\end{array}$ \\
\hline (possession & mihi DAT & id NOM.N.SG & est "is" \\
\hline change 2 & Unmarked subject & Marked patient & Vagr: S \\
\hline Latin & ego NOM & id ACC & $\begin{array}{l}\text { factum habeo } \\
\text { PPP.ACC have.1 SGS } \\
\text { habeo ("I have") }\end{array}$ \\
\hline (possession & ego NOM & filium ACC & \\
\hline
\end{tabular}

\begin{tabular}{|l|l|l|}
\hline NP1 & NP2 & V \\
\hline $\begin{array}{l}\text { Oblique Agent } \\
\text { or possessor }\end{array}$ & $\begin{array}{l}\text { Nominative patient } \\
\text { or possessed }\end{array}$ & $\begin{array}{l}\text { Participle.agrNP2 } \\
\text { or be }\end{array}$ \\
\hline $\begin{array}{l}\text { Nominative Agent } \\
\text { or possessor }\end{array}$ & $\begin{array}{l}\text { Accusative Patient } \\
\text { or possessor }\end{array}$ & $\begin{array}{l}\text { Participle+have } \\
\text { or have }\end{array}$ \\
\hline
\end{tabular}

1.3.Further evolution of past systems in IA

Eastern languages such as Bengali underwent a further evolution similar to the "have" restructuration in Romance languages, yet without "have" verb:
(18) a. āmi boi.ța por.l.ām
$1 \mathrm{SG}$ book.DEF read.PST.1SG 'I read the book'
b. tumi boi.ta por.l.e (BENGALI)
2 book.DEF read.PST.2
'You read the book'

As noted by S. K. Chatterji, the new personal endings in the past $(1 \mathrm{~s}-\bar{a} m, 2 \mathrm{~s}-i,-e)$ are distinct from the inherited personal endings of present $(1 \mathrm{~s}-i, 2 \mathrm{~s}-i s h, o)$ and come from pronominal stems. As for the $-l-$, which is now analyzed as a past tense marker, it originates from an adjectival suffix, the same as Hindi -il-(rang.il. $\bar{a}$ "colour.ed.M.SG), a further evidence of adjectival nature of the predicate in the pre-ergative alignments (Chatterji 1926: 928, Tessitori

\footnotetext{
${ }^{5}$ In French, "un siège d'état".
} 
1914). Its re-analysis as a past (PST) tense marker corresponds to the renewal of the preergative alignment into a nominative alignment ${ }^{6}$. Chatterji in 1926, following the then usual interpretation, considers this evolution as a shift from passive to active, but he gives all the elements for a proper understanding (regarding the nominal feature of the old form, hence the stative rather than passive meaning of the original pattern $)^{7}$.

Similarly, Eastern Hindi, which also displays the same suffix -l- in the definite past, is systematically interpreted as a shift from passive to active in Saxena (1937: 247sq) for Bhojpuri, Jha for Maithili (1985 [1958]: 492 sq) and Tiwari (1966: 171) for Awadhi: "when the original passive construction was lost in Bhojpuri as in other Magadhean dialects, the Prakritic constructions with the passive participle became a regular verb in Bhojpuri, and it began to be conjugated by adding personal terminations which came from the radical tense as well as from the $s / h$ future".

Clearly, all Eastern languages exhibit a complete evolution in two stages, the latter similar to the 'have' realignment in Latin and Romance languages, whether it is called a passive-active shift or an inversion of the argument structure retaining the stative meaning (Benveniste). In short, it can be considered that they completed the full cycle from nominative to pre-ergative and back to nominative (de-ergative new shift), and have been more innovative than Western IA languages. Among IE languages, this innovation is shared by modern standard Persian, which, like Bengali, without "have", shifted the pre-ergative alignment of (6-10), with genitive agent, into a nominative alignment (19), whereas other Iranian languages like Pashto or Kurmanji developed ergativity. The pronoun retains its oblique form and is reanalysed as a nominative, like Hindi main, while personal endings developed out of pronominal affixes:

$\begin{array}{ll}\text { man kard.am } & \text { to kard.i } \\ 1 \mathrm{SG} \text { do. } 1 \mathrm{SG} & \text { 2SG do.1SG } \\ \text { 'I have done }>\text { did' } & \text { 'you have done }>\text { did' }\end{array}$

Western languages in contrast completed the cycle from nominative to pre-ergative and full fledged ergative alignment by reinforcing the ergative case (cf. section 3$)$. Hindi/Urdu (ex. 1-2) can be seen as the more representative, even if a high ranking patient blocks the agreement, which is not the case in Marwari, certain Marathi dialects, and Gujarati ${ }^{8}$. But the fact that first and/or second person agents are unmarked in certain languages (Marwari, Shekhavati, Gujarati, Marathi, Panjabi) and that verb can agree with the agent, may be interpreted as a sign of a transitional stage towards a nominative alignment. For instance, with a third person agent, (20a) in Marathi and (21a) in Punjabi pattern exactly like (1a) in Hindi/Urdu: ergative case and only gender-number agreement with the patient on the participle-like predicate. But with a second person agent, the verb has a second person ending $(-s)$ after the gender-number agreement with the patient in Marathi (20b), and both in Punjabi (21b) and Marathi the first two persons are unmarked.

$$
\begin{array}{lll}
\text { tyān } \bar{\imath} & \text { top } \bar{\imath} & \text { kadh.l. } \bar{\imath} \\
\text { 3M.SG.ERG } & \text { hat.F.SG } & \text { take.PST.F.SG } \\
\text { 'He took the hat' }
\end{array}
$$

(MARATHI)

one ihi kamīzã

kharīdi $\tilde{\bar{a}}$

(PUNJABI)

\footnotetext{
${ }^{6}$ The fact that the same suffix may also occur at other tenses (certain persons of the future in Bhojpuri for instance) shows that this recent re-analysis as a tense marker is limited to Bengali

${ }^{7}$ An "archaic" remnant of the old system survived in the classical language with the $-e$ ending for transitive past.

${ }^{8}$ Old Gujarati example from Chatterji: tene rānā.ne joi [by.him in.reference.to.the queen was.seen] "he saw the queen"; modern Gujarati from Cardona (2003: 670): urmilā.e tāmārā dikrā.ne joy.o [Urmila.agent your son.ms.object see.ms] "Urmila saw your son". With original gloss.
} 
3SG.ERG these shirt.F.PL give.F.PL

'He bought these shirts'

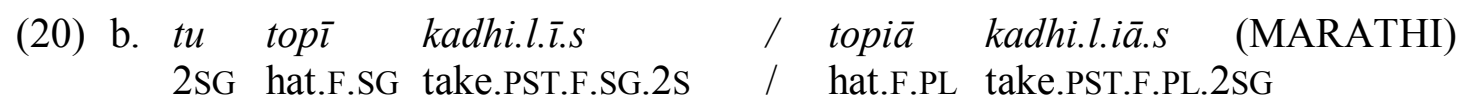

'You took the hat /hats'

(21) b. maĩ (tū /tusī) ihi kamīz $\tilde{\bar{a}}$ kharīdi $\tilde{\bar{a}}$

$1 \mathrm{SG}$ (2FAM 2.) this shirt.F.PL buy.F.PL

'I (you) bought these shirts'

This person split, also attested in Gujarati, with first and second person pronouns in the unmarked form, differs from other ergative languages in the world with hierarchical split (first persons in the absolutive case) by the fact that object agreement is maintained, with (20b) or without (21b) subject agreement. It could then be interpreted as a first step in a deergativation cycle. However, other important facts in such languages suggest that ergativity extends far beyond the domain of the past in these languages.

\section{Modal future}

\subsection{The data up to early New-Indo-Aryan}

Many scholars, starting with Kellogg (1875) and Beames, then Bloch and Chatterji, have noticed that in many Indo-Aryan languages the future and modal clauses displayed the same alignment as the past one. This alignment did not survive with its oblique/instrumental agent and verb agreeing with patient, because of the competing survival of the old synthetic future in some languages $(s y a>s>h)$ or of new periphrastic expressions involving the verb 'go', or 'reach/touch' in others. But where it prevailed, up to the $15^{\text {th }}$ century, it was systematically interpreted by the above mentioned scholars as the continuation of the Sanskrit passive obligative verbal adjective (OVA) in -tavya, such as kartavyam, "to be done, do-able". This verbal adjective required the same argument structure as the past verbal adjective, a nominal sentence with instrumental agent and agreement with the patient:

(22) mayā tat kartavyam

(SK)

1SG.INS this.NOM.N.SG to.be.done NOM.N.SG

'I have to do this'

This construction prevailed both in the East and West for expressing obligation, as evidenced in the Asoka's edicts (from the West in (23a) and from the Magadhean East in (23b), same gloss and meaning:

(23) a. idha na kimci jivvam

(23) b. hida no kimci jive

arābhitpā prajuhitavyam na ca samājo kattavyo (PRK) here no some living alabhitu pajohitavye no pi ca samāje kill sacrifice. no and assembly do NOM.N.SG CV OVA.NOM.N.SG NOM.M.SG OVA.NOM.M.SG

'One should not sacrifice by killing a living creature nor hold a meeting' (it should not be sacrificed by killing a living being nor a meeting should be held) 
It is the prevailing way for expressing obligation in classical narration up to the $10^{\text {th }}$ century (24), for transitive but also intransitive verbs, which occur quite commonly, with agreement is in the neuter, and agent in the instrumental':
a. na kșeptavya
brahma-vādino
na cāvamānyāh

(SK)

NEG neglect.NOM.OVA.M.PL Brahman-knower.M.PL NEG contempt.OVA.NOM.M.PL '(You) should not neglect nor contempt those who know the Vedic word'
b. tribhir
yātavyam
/ tvayā gantavyam
three.INS.PL go.OVA.NOM.N.SG
'The three have to go'
2S.INS go.OVA.NOM.N.SG
'You have to go'

The meaning, originally modal (obligation), gradually shifted to a temporal meaning of future, echoed by the translations. Verbal endings tend to be eroded with the gradual loss of gender number marks in the East, yet early Bengali (Chatterji: 964sq.) still shows gender agreement (25a) with the unmarked patient, whereas with a marked one, there is no agreement (25b), as is the case with intransitive verbs (25c), and similarly Awadhi (26):
a. mä dibi piricha
1SG.INS give.b.F question.F.PL
(OLD BENGALI)
'I will ask questions'

(25) b. tabẽ to.ka rakhiba kona jāne (OLD BENGALI)

then 2.ACC protect. $b$ which person.INS

'Then who will protect you?'
c. thakiba, khaïba maï
stay.b. $\varnothing$ eat- $b-\varnothing \quad$ 1SG.INS
'I will stay, eat'
(OLD BENGALI)

(26) a. karaba maï sevā

do- $b-\varnothing$ 1.INS service

(OLD AWADHI)

'I will serve' (Nur Mohammad 32)
(26) b. anucit kahaba na paṇdit kehi (OLD AWADHI)
unsuitable say. $b$ NEG pandit INDEF.OBL
'No priest will say it [is] not proper' (Tulsidas)

\subsection{Kurylowicz theory of the parallel between past (perfect) and future (modal)}

The traditional assumptions regarding the nominal sentence involving passive participles in ancient IE languages allows Kurylowicz (1960 [1931], [1953]) to perceive an extremely interesting analogy, dismissed by Benveniste on semantic ground ${ }^{10}$. Inquiring into the evolution of verb tenses in Romance languages, Kurylowicz noticed a striking similarity between the periphrastic renewals which occurred both in the past and in the future. In both case, the renewal occurred around the same period, in two stages, and resulted in the same morpho-syntactic restructuring. The first change was the transition from the finite verb forms

\footnotetext{
${ }^{9}$ Contrary to the past passive participle; which only rarely allowed instrumental agents: asmakam abhipretam bhavantam [1PL.INS go.OVA.NOM.N.SG] "we have come", aștakasya grhe mayā ușitam [Astaka.GEN house.LOC 1.INS stay.PPP.NOM.N.SG] "I have stayed in Astaka's house" (Bloch 1906: 36).

${ }^{10}$ The "have" restructuring of the future analysed by Kurylowicz is deemed by Benveniste as marginal and restricted to religious predication with a meaning of predestination. It is however doubtless that these are the forms at the origin of the modern future in Romance languages.
} 
with nominative subject to the participial predicate with dative subject, ending in the generalization of the verbal adjective in Late Latin (-nd-), similar to Sanskrit maya krtam and mayā kartavyam:
a. mihi virtus
colenda
est
(LATIN)

1SG.DAT virtue.F.SG.NOM cultivate.OVA.NOM.F.SG be.3SG

'I shall/have to cultivate virtue'
b. mihi id
faciendum
est
(LATIN)
1SG.DAT this.NOM.N.SG do.OVA.NOM.N.SG be.3SG
'I shall/have to do this'
(27) c . Carthago
delenda
est
Carthago.NOM.F.SG delete.OVA.NOM.F.SG be.3SG
'Carthago is to be destroyed'
'Carthago should/will be destroyed, (we) shall destroy Carthago'

The meaning of the Latin gerund in -(e)ndus was originally modal, with a strong sense of obligation (as it is in Asoka's statement in (23), and the transition towards future tense occurred only after the second stage, namely after this dative alignment underwent a second transformation with verb "have" which he calls an "active transformation": as with the "have" perfects, the new alignment changes the argument structure from the dative to the nominative of the agent, and the verb from "be" to "have":
(28) ego
virtutem
coleri
habeo (LATE LATIN)
1SG.NOM virtue.F.SG.ACC cultivate.PSF.INF have.1SG
lit. 'I have virtue to be cultivated': 'I shall cultivate virtue'

The passive infinitive involved in the statement may be responsible for the original semantic change in the modal meaning of the form when it emerged in the early centuries, in the discourse of Christian predicators (he has this to be done: it is predicted that he will act so, as an accomplishment of Christ's will) ${ }^{11}$. When this particular meaning got lost, the simple temporal meaning started to generalize, and the passive infinitive originally required shifted to an active infinitive, which is still used in Romance languages (fused auxiliary after infinitive):
a. ego cantare habeo
1SG sing.INF have.1SG 'I will sing'
(LATE LATIN)
b. je chanter -ai (FR) yo cantar-é (SP) io cantar-e (IT) (ROMANCE LG)
'I will sing'

Morphologically, the analogy of perfect and future is still very perceptible in all Romance languages although all have fused the "have" auxiliary into future endings whereas it is still a separate auxiliary in the perfect, and some have kept the initial aspiration of "have" while others have not (SP: he cantado/cantar.é has cantado/canta.ras, ha cantado/cantar.a; etc. FR: ai chanté/chanter.ai, as chanté/chanter.as, a chanté/chanter.a, etc ). The conclusion drawn by Kurylowicz (1965) out of this parallel history in IE is that perfect and future, in contrast to the present, are not active and do not aim at depicting actions but viewpoints (from the present) ${ }^{12}$.

Table 3 summary of the analogies captured by Kurylowicz

\begin{tabular}{l|l|l|}
\hline alignment & perfect & future \\
\hline${ }^{11}$ It may also explain the reason why Benveniste rejected any analogy between future and perfect. \\
${ }^{12}$ A conclusion reached also by Benveniste on different grounds.
\end{tabular}




\begin{tabular}{|l|l|l|}
\hline $\begin{array}{l}\text { Nominative: synthetic verb form, NOM } \\
\text { subject, person agreement Latin }\end{array}$ & (ego) feci/cantavi & (ego) facebo /cantabo \\
\hline $\begin{array}{l}\text { Non-nominative : participial verb, DAT } \\
\text { agent Late Latin, no person agreement }\end{array}$ & mihi factum est & mihi faciendum est \\
\hline $\begin{array}{l}\text { Nominative: V +have, NOM subject, } \\
\text { Person agreement (Later Latin) }\end{array}$ & (ego) factum habeo & (ego) fieri/cantari habeo \\
\hline $\begin{array}{l}\text { Nominative: V+“have, NOM subject, } \\
\text { person agreement (new Romance) }\end{array}$ & $\begin{array}{l}\text { j'ai fait/chanté } \\
\text { io he cantado }\end{array}$ & $\begin{array}{l}\text { je fer.ai/chanter.ai } \\
\text { io cantar.é }\end{array}$ \\
\hline
\end{tabular}

\subsection{Indo-Aryan modal future}

Whereas, out of the many synthetic forms for past in Vedic (jagāma, agacchat, agamat), only the verbal adjective survived (sa jātah/yātah) in Middle Indian, the situation for future differs considerably because the old sigmatic future did not disappear. Although the $-b$ - form $(<-$ tavya) appears in some Western languages (māribo "I will strike" in Kannauji, mārabo in Braj), it mainly developed as a future in Eastern languages, like Bengali, Maithili, Magahi, Awadhi, Bhojpuri ${ }^{13}$. Apart from the range of diffusion of the new periphrastic structure, the parallel holds true also for the second phase of this evolution, namely the shift from an instrumenta1/oblique alignment to a nominative alignment, whether or not we call the first a passive sentence (older grammarians) or a pre-ergative alignment (here above).

What happened after the initial stage of early Indo-Aryan (around the $15^{\text {th }}$ century) is a shift towards the nominative alignment similar to the shift observed in the perfect, and usually also called an "active transformation" (by Saxena, Tiwari, Chatterji). Such scholars noticed this similarity, particularly when commenting on the new personal endings crucial to the "active" transformation and nominative alignment: "the affixes for the first, second and third persons masculine and feminine singular and plural are in a line with those of simple past" (Tiwari 1966: 161). Chatterji (1926: 987) is the most explicit, not only noticing that "the affixes are exactly on the lines of the past" (set A for $2^{\text {nd }}$ person: $\left.i, e\right)^{14}$, in contrast with those for present ( set $\mathrm{B}$ for $2^{\text {nd }}$ person intimate $-i s h$, and $2^{\text {nd }}$ person neutral- $o$ ), but that the shift in alignment ("construction") occurred at the same time.

(30) Future

Past

Present ami boita porbo / tu porbi / tumi porbe, etc. ami boiț porlām / tu porli /tumi porle ami boita pori /tu porish / tumi poro
V-b-personA

V-1-personA

V-personB

(BENGALI)

These parallels mean that, in the absence of verb "have", the nominative shift occurred in a very similar way, out of dative or instrumental or genitive alignments with verbal adjective. The intervention of "have" in Romance languages helps understanding that, rather than a passive/active shift, the change deals with an inversion, with the new predicative expression like the old one equally distinct from action predicates. This of course does not entail a present linguistic perception of these forms as statives, particularly when the simple form for the past got restricted to anteriority (preterit), while perfect was renewed with a "be" auxiliary. (Cf. section 1.1).

What is intended in Benveniste's discovery, at a time when the French perfect also gained currency as an anterior in the spoken language, is that, in conformity with its history in IE, the perfect, in its pre-ergatival form as well as in its "de-ergatived" form, does not basically

\footnotetext{
${ }^{13}$ Where it was used at all persons up to the re-introduction of the old sigmatic future for the $1^{\text {st }}$ and $2^{\text {nd }}$ persons in Western Bhojpuri (Saxena 1937: 261).

${ }^{14}$ First person now shows less clear analogy, but it is labial and was previously more visibly stemming from the same affix.
} 
express an action, in contrast to the present. No wonder then that the case markers display strong affinities with locative or dative case markers in many IA languages. No wonder that the alignment too presents strong similarities with the so-called 'dative subject' constructions.

\section{Case markers: from a syncretic locative to new localizing words}

\subsection{The old morphological case: a locative}

Case markers in the form of postpositions are recent, particularly for the agent, which can occur without postposition until at least the $16^{\text {th }}$ century. The standard case in Sanskrit and Prakrits for transitive agents in the past (and modal future), in statements treated as passive by grammarians (Speijer 1886: 50), which we can consider pre-ergative, was the instrumental, or optionally for pronouns the genitive (3). Whereas the old genitive survived in modern Persian for the first person pronoun (man, now a nominative), in many Indo-Aryan languages it is the instrumental form which survived, for instance Hindi main, from Sk instrumental mayâ, in the first person, or tain in certain dialects for the second person, in analogy with first person. Regarding nouns, instrumental and locative soon converged, and in early NIA the Sanskrit instrumental -ena has evolved into $-e$, $-e n$, or $-i$, a form also corresponding to the locative (Sk $-e>-i,-e$ ) as noted by Tagare (1948: 119), sometimes enlarged in -ai. (Kellogg).

This form survived up to modern IA languages with a locative meaning (Bengali and Gujarati: $-e$, Marathi and many regional "dialects" of Hindi: $-i$ ), but not in standard Hindi/Urdu where the locative is now postpositional. There is however no doubt about its use as both instrumental and locative marker in the old language, as well as agent of transitive past verbs, and the data from the $14^{\text {th }}$ century display the three forms $-e,-i$, $-a i$, with sometimes an "extended" realisation $-y a$, in various meanings (Strnad 2012). These are the forms found in Kabir, one of the oldest testimonies, with Gorakhnath, of early Hindi, or rather of what is now called Hindi and was then a blend of several speech varieties ranging from Braj in the West to Awadhi in the East. Examples below illustrate locative (31) and instrumental (32) meanings:

(31) a jihi ghați rāma rahiyau (SANT BHASHA: Kabir)

REL.LOC body.LOC Rama stay.3M.SG

'In which body Rama resided?' (65.2)

(31) b. ābari dīsai ketā tārāa

sky.LOC be.seen.3M.PL how.many star.M.PL

'How many stars we have seen in the sky!' (146.1)

(32) a. kāranii kauni [āi jagi] janamyau?

cause.LOC which.LOC [come.CV world.LOC] be.born.M.SG

'By which cause was he born [having come in the world]?' (224.2)

(32) b. premi harījana bhīna

love.LOC God.children be.drenched.M.PL

'He devotees were drenched in/by love'

The semantic closeness of locative and cause or means visible in (32b), as also in expressions such as "in/by doing so", may have triggered the semantic merge parallel to the formal merge of locative and instrumental case markers.

The same case is used for agents in transitive past clauses, with the predicate (in a participle form) agreeing with the patient:

(33) a. guri diyā palītā (SANT BASHA: KABIR) 
guru.LOCgive.M.SG stick.M.SG

'The guru (spiritual master) gave the stick' (8.3)
b. rāma guna belarī re avadhū gorașanāthi jã $n \bar{\imath}$
Ram quality small.plant.F.SG o Avadhuta Gorakhnath know.F.SG
'Gorakhnath knew, ô Awadhuta, the plant of Ram's quality (devotional love)'

The enlarged form -ya similarly occurs in both locative (dsasv.ai $d v \bar{a} r . i$ "at the tenth door"), instrumental (rid.ai "with heart") and ergative (or pre-ergativel) functions:
tãnanã
bunanã
tajy $\bar{a}$
kabīr.ya
(SANT BASHA: Kabir)
stretch.INF.M.SG weave.INF.M.SG renounce.M.SGKabir.LOC
'Kabir renounced warping and weaving' (27)

The fact that in modern languages such a form survives only as a locator (for time or space), suggests that, whatever its origin and in spite of instrumental traces in the nasalized forms of the suffix in certain dialects $(-\tilde{\imath},-\tilde{e})$, it came to be more and more associated with simple location, in a non allative meaning, and it is not by chance coincidence that it is found as an adverbial marker in Kabir (ât.i "in the end"). True, the causal meaning is not radically opposed to the locative meaning (32b: "in/by"), but they are found in locative functions in all languages where they survived, in the $-i$ or $-e$ form (Marathi: 44a, Gujarati 41). One more argument for considering its basic meaning as locative rather than instrumental is the morphological material used later in order to reinforce the agentive case in languages which developed a full-fledged ergative construction ${ }^{15}$.

\subsection{Postpositional new ergative case}

The most common marker for the ergative case in NIA is now ne or forms akin to ne (ne/ni in Marathi, ne in Gujarati, ne in Panjabi, Urdu, Hindi, na in new Garhwali). Ne does not seem to have appeared before the end of $14^{\text {th }}$ century (Namdev has tayyane for the agent case in the $2^{\text {nd }}$ person) and was not generalized then. Beames (1871: 295) suggests a derivation from lagi rather than the old instrumental -ena (a highly improbable evolution since -ena is known to have regularly shifted to $-e$ or $-\tilde{e}$ or a simple nasalization) ${ }^{16}$, most scholars of the $20^{\text {th }}$ century follow L. Tessistori, who first established a plausible etymology for ne/nai and its variants in 1913 (1913; 1914-16: 226-7). According to him naĩ, naï, nī, ni, ne is a shortening of kanhaĩ found in Old Rajasthani texts. Kanhaĩ (<Apabramsha kannahi $)$ comes from the reconstructed * karnasmin (from Sanskrit karne, the locative case of the noun "ear"), a locative form meaning "aside, near". Trumpp (1872: 401) also gives the original meaning "near" for naï/ne. This meaning, according to Tessitori, "may be understood either in the sense of the locative "near to" or of the accusative-dative "towards, to". The second meaning is the origin of the Western marker for goal (Panjabi DAT/ACC n $\tilde{\bar{u}}$ ), and the first one of the ergative markers of the ne type. This derivation, accepted by Chatterji (1926) has been followed by Tiwari (1961) and Chatak (1966) for Western Hindi language and dialects. The shortening of kanhi/kanhai into nhai > nai is convincingly evidenced by Tessitori, with examples from old bardic texts $\left(14-16^{\text {th }} c\right)$ such as:

\footnotetext{
${ }^{15}$ If no postposition, agent is in the oblique (Jaisalmeri, Siraiki), a case otherwise used only for locative meanings, not instrumental or ablative, if not formally recognizable as a development of the old locative.

${ }^{16}$ Hindi main, which may reasonably be assumed to derive from a reinforcing of the classical instrumental form mayâ via *mayena (Chatterji: 744) shows only a nasal ending vowel, as all forms derived from the Sanskrit -ena. Another fancy etymology is the derivation from nyāya ("manner < rule"), questioned by Bloch (1914/1935), who however does not suggest any alternative.
} 


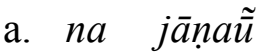
kihã kanahī achaï

(OLD RAJASTHANI)

NEG know.PRS.1SG where LOC be.PRS.3SG

'I don't know where he is'

(35) b. cāräïnaï nirmala nīra

road LOC pure water

'A limpid lake close by the road',

(36) a. $\tilde{\bar{a}} v y \bar{a} \quad r \bar{a} \quad k a n ̣ h a i$

come.M.PL king LOC/ALL

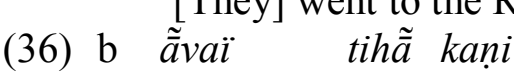

'[They] went to the Raja (king)'

come.3SG there LOC/ALL

' $[\mathrm{He}]$ goes there'

c. te savih $\tilde{\bar{u}}$ naï karaũ paranām

3PLall.OBL LOC/ALL do.PRS.1SG salutation

'I bow to all of them' (in front of/ for)

This postposition, with either locative or allative meaning above (hence the gloss) is the one used as a marker of agents in transitive past clauses, a function which occurred later and is according to Tessitori, "rare in the old literature, but has grown today and is now (1914) the most frequent marker for agents in Marwari and Malvi (Western Rajasthani) as it is in Gujarati, Panjabi, Nepali, Hindi”.

\section{(37)}
adiśvara naï
$\operatorname{dikṣ\overline {a}}$
lidhi
(OLD RAJASTHANI)
Adishwara LOC/ERG ritual.consecration.F.SG take.F.SG
'The Adishvara took the diksha' (consecration)'

Tessitori derives the Gujarati ergative marker $-e / n e$, which retains the original retroflex of karne "ear" (locative), as well as the Gujarati dative marker ne, from the same basis. In Gujarati, there are two forms for the ergative case, ne or -e (not clearly allomorphs although ne tends to occur after a vowel ending noun and -e after a consonant ending one ${ }^{18}$ ). Examples (38-39), adapted from Cardona \& Suthar 2003 for transcription and gloss, shows the cognate ergative and dative markers, (40) show the cognate agentive and locative markers:
ai.ne
bahan.ne sundar kanthī
dekhadī
3SG.ERG sister.ACC beautiful necklace.F.SG show.[PST]F.SG
'He showed his sister a beautiful necklace'

(39) rāma ne chokro gamyo

Ram DAT child.M.SG be.pleasant/like. M.SG

'Ram liked the child'
(40) rameś.e caupḍ̄ kharīd. $\bar{\imath}$
Ramesh.ERG book.F.SG buy.F.SG
'Ramesh bought a book'

\footnotetext{
${ }^{17}$ Other example with the meaning "near, close to": mithyādrșthi loka kanhaĩ srāvai vasirau nahĩ : "a shravaka (hermit) should not live near heretics".

${ }^{18} \mathrm{G}$. Cardona, personal communication.
} 
The -e locative (directly inherited from Sk, and cognate to the Kabir locative case above) is attested in old texts such as the Jain Gurjar Kavyo in Desai's edition (1926) both for marking agents of transitive past verbs and location, whereas $n e$ is used for marked objects:

a. jamunajī.n.e tat.e

(OLD GUJARATI)

Yamuna.HON.GEN.LOC bank.LOC

'On the bank of the Yamuna river' ${ }^{19}$ (630)

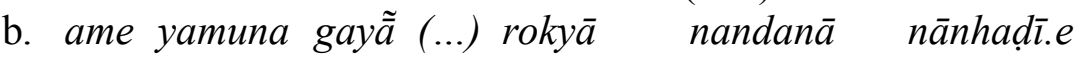

1PL Yamuna go.M.PL stop.M.PL Nanda.GEN small.boy.LOC/ERG

'We have been to the Yamuna (...), Nanda's boy stopped [us] ([we] were stopped by Nanda's boy)'
Yasoda! Vāro
re tārā
kān.ne re
$j \bar{l}$
Yasoda retain.IMP INTERJ your Kana.ACC
INTERJ HON
'Yasoda, please, stop your Kanha (Krishna)'

Panjabi displays a similar morphological relation between the DAT/ACC case, also used for

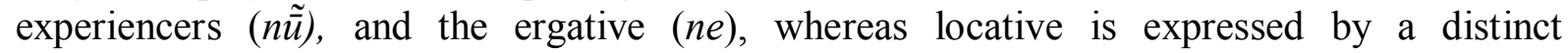
postposition. Bangaru, a language close to both Hindi and Panjabi, in the dialect described by Jagdev Singh (1970: 69) uses the same nai for ergative, marked accusative, dative. In the early $20^{\text {th }}$ century Konkani, the $n, n a, n \bar{l}$ form means "to" and similarly $n e$ in Bhili, ne/nai in Rajasthani has both meanings "by" and "to" (Grierson). In such languages as Panjabi, Konkani, there is an obvious relation between dative (allative) and ergative markers, in Gujarati as in old Hindi (Kabir), there is an obvious relation between locative and ergative. This morphological analogy supports the view that there is also a semantic relation between the transitive perfect and the locative sentence (rather than with the classical transitive clause with source and target/goal).

There are also languages which use the ergative marker for instrumental, an extension already present in some less frequent uses of the morphological oblique case in Kabir. Marathi is one such example, with -ne used for inanimate causes, instrument or medium, whereas the dative case is $l \bar{a}$, from a different origin. Similarly Garhwali in the North marks some instruments (cause, medium) with -ana, -na, one of the two postpositions used for ergative case:
a. bhukh.ana mare vakh.ana āye (GA
hunger.INS died there.INS come.PFV.M.PL
(GARHWALI)
'They died of hunger' 'they came from there'
b. mi.na/la nauno baüt na māri
1SG.ERG child cane INS strike.PFV.SG
'I hit the boy with a cane'

The other and more traditional postposition for ergative case, $l a$, is not used for instruments in Garhwali, but the cognate le is used in certain dialects for dative, besides the more common khuni (interestingly derived from karne by Chattak 1966: 55sq) or sāṇi (originally 'with'). La and $l e$ are cognate with the Marathi dative marker $l \bar{a}$, and with the Kumaoni ergative marker le. Whereas standard Kumaoni uses le both for instruments and ergative agents, with a distinct dative marker (Stronski: 2010), the fact that this le is cognate with other dative markers in IA is significant. Its origin, besides, provides one more argument to the locative hypothesis

\footnotetext{
${ }^{19}$ Like in Hindi, the genitive postposition is an adjectiving suffix and the noun in the genitive inflects for gender, number and case in agreement with the head noun.
} 
formulated by Benveniste: le/la (and its allomorphs $-l, a l$ ), ${ }^{20}$ is assumed by most scholars to derive from lagya > lage >laï, le "having come in touch with", "for the sake of", "with the object of" (Juyal 1976). Not surprisingly the dative marker $l \bar{a}$ in Marathi is also supposed to derive from lag/lāg (> lāgi, "up to, for the sake of"), according to Turner (Old Marwari lag "up to, until" ". It is obvious that both locative and dative, although quite distinct now in most IA languages, stem from a common notion of vicinity and adjacency, presented either as dynamic (entity aimed at: dative, goal or marked patient) or non dynamic (localizer of the process: ergative).

The allative as well as the locative meaning is in contradiction with the notion of source which is required if we accept the idea that ergative alignment is a mirror inversion of the nominative transitive scenario (with the goal as its first unmarked argument corresponding to the Patient / pivot, and the source in the ergative/agentive case), since etymologically in IA the ergative Agent, not the Patient, is itself encoded as a goal if not as a simple locative. It better fits the model proposed by Benveniste, with the subject viewed as the locus of a state and not a source. It also fits the parallel with the non nominative alignment of modal future, both transitive and intransitive, which prevailed up to the $15^{\text {th }}$ century in many IA languages and is still recognizable in the expression of various modalities in some IA modern languages.

\section{Case alternations (DAT/ERG) in modal statements}

A supplementary evidence for a deep relation between ergative and locative (or dative/experiential) alignments can be found in the case alternations involved in the representation of certain modalities in Western IA languages.

\subsection{Modalities with a predicate formally related to the old verbal adjective}

Marathi did not retain the -tavya passive obligative participle for the future as did Bengali and Eastern Hindi for instance with their - $b$ - future, but it retained it in a way somewhat closer to he original model: the form itself retained its semi-vowel -v-, and the meaning its modal feature. The verbal forms for obligation and potential in $-\bar{a} v / a v$ - are inherited from the -tavya verbal adjective, and they also maintain the old syntax with an instrumental 'subject' (Chatterji 1926: 966, Joshi 1900: 468). As commented by Bloch (1970: 264), "this syntax, with the logical subject in the instrumental, is similar to that of the form for past". The reason why Bloch (and others, before the notion of ergativity was known) describe the agentive case as an instrumental is obviously the Sanskrit original structures for both past and obligation, with instrumental subject.

The following pair quoted by Bloch (1970: 264) from Joshi (1900: §468), with obligative meaning, shows the "active conversion" of what he calls a "passive" structure into an "active" structure in a way very similar to what happened in Bengali for future. (44a) is a quasi ergative alignment with the $n \tilde{e}$ (ne/ni today) marker although the verb is intransitive, agreeing in the neuter whereas (44b), competing in the same meaning in the $19^{\text {th }}$ century, shows a nominative alignment with a verb agreeing with its nominative subject:

$\begin{array}{llll}\text { a. tyāne } & \text { ghari } & y \bar{a} v \tilde{e} & \text { (MARATHI) } \\ \text { 3M.SG.INS/ERG home.LOC } & \text { come.SBJV.N.SG } \\ \text { 'He should come home' } & \end{array}$

\footnotetext{
${ }^{20}$ Example from Grierson: hamanle callo mār cha [1PL-ERG bird-M.SG strike PFT-M.SG] 'We killed the bird']. apnā hātel khān banuni [REFL-OBL hand-INS food make-PST] '(they) prepared food by their hand'.

${ }^{21}$ Tiwari also suggests a possible derivation from labhati "acquire, benefit", in conformity with the meaning of the beneficiary but usually not retained.
} 
b. to gharĩ $y \bar{a} v \bar{a}$

3M.SG.NOM home.LOC come.SBJV.3M.SG

'He should come home'

In contemporary Marathi, according to Pandharipande (1997: 290; 2003: 711), ergative case (which she glosses as agent) has the optative meaning ("he/she may go home": her translation for tyāne/tine ghari $d z \bar{a} v e$ ). When the verb is transitive, agreement is always with the patient even if in Modern Marathi the $1^{\text {st }}$ and $2^{\text {nd }}$ persons do not inflect in the ergative alignment:

$$
\begin{aligned}
& \text { c. } m \bar{\imath} / \text { tyāne kāma karavī(t) } \quad \text { (MARATHI) } \\
& \text { 1SG/3M.SG.ERG job.M.PL do.v.M.PL } \\
& \text { 'I/he may do the jobs' (Pandharipande 1997: 290-1) }
\end{aligned}
$$

According to other modern writers there is now a difference in meaning, and the ergative clause is obligative while the nominative one is "optative" (Wali 2004a: 31): "The obligative marks the subject in the ergative while the optative uses the nominative subject. Both obligative and optative add the suffix $-v a$ to the verb stem" (to ghari jō $v \bar{a}$ "may he come home"; ti dhāva-avi "she may run", tine dhāva-ave "she must run", from Wali 2004b: $228^{22}$ ). The potential modality ( $-a v$, wrongly interpreted by some as a causative suffix) in Marathi is also derived from the obligative verbal adjective (passive participle in -tavya), and it also allows a case alternation, yet without involving the nominative, that is, without "active" transformation. The case alternation here involves two oblique forms with the same

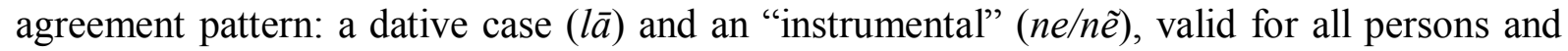
for intransitive verbs as well as transitive:

$$
\begin{array}{lr}
\text { majhyāne / malā cālavlẽ } & \text { (OLD MARAT } \\
\text { 1SG.INS / 1SG.DAT go.POT.PST.N.SG } & \text { (Bloch 1909: 265) } \\
\text { 'I could/was able to go' }
\end{array}
$$

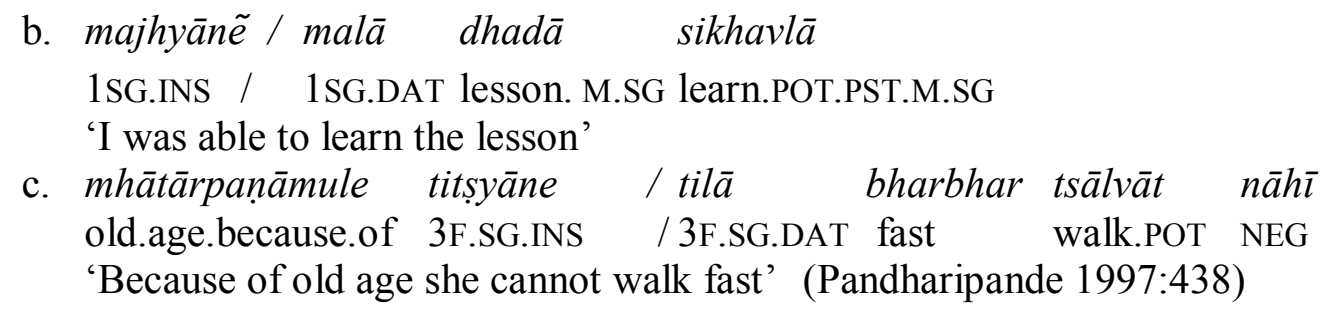

Whatever the glosses adopted by grammarians, and the reasons for them (intransitivity may embarrass, $1^{\text {st }}$ person is no longer compatible with the ergative marking, ne also functions as an instrumental in the language), it is clear that the argument structure, and the agreement pattern is similar to those used for transitive past processes and the marker is cognate, simply affixed to the genitive form of pronouns at all persons, whereas it is affixed only to the $3^{\text {rd }}$ person in their oblique forms in ergative clauses (20b).

Whatever the semantic differences between ergative/instrumental and dative in the potential and ergative and nominative in the obligation/optative, which may depend on dialects and even speakers, what is interesting here is that the possible choice of dative for type (45) clauses clearly shows the relation between both case markers, while the possible choice of nominative in type (44) clearly shows that this ex-passive then stative predications, directly inherited from the old construction with instrumental agent and passive verbal adjective, are now perceived as standard "active" clauses. Moreover, such alternations also show that the

\footnotetext{
${ }^{22}$ With the same argument structure as in ergative clauses, when the verb is transitive with marked object : mini ni Ravi la khadsa-av-a (Mini.ERG, Ravi.ACC scold.AV/ SUBJ.NS) "Mini should scold Ravi” (Wali 2004b: 228).
} 
ergative (instrumental/agentive according to scholars glosses) alignment is not restricted to transitive verbs, and even unmarked pronouns (first and second persons) require a neutral verb $(-e)$ in obligative structure (46a), whereas verb agrees with the subject if nominative in potential clauses (46b), both examples from Wali (2004b: 238):
a. tyāne / tu hansāve 3M.SG.ERG / 2SG laugh.SBJV.N.SG
(MARATHI)
'he/you should laugh'
b. $t \bar{u}$ hansāvo
2SG laugh.SBJV.2M.SG 'You may laugh, I wish you laugh'

Similarly in Gujarati, both modalities (potential and obligation) involve an oblique agent with a $-a v / v$ form of the verb reminiscent of the old verbal obligative participle, and allow a case alternation involving ergative marking (standard ergative marking in 47). In (48) the verb root is suffixed with -van-, followed by gender number agreement, a nominal/adjectival form meaning "have to", with $-v$ - not glossed by Cardona \& Suthar, $-a$ glossed as obligative, $-n-$ explained as relator which connects with following elements (Cardona \& Suthar 2003: 677) and this form is followed by 'be' auxiliary (che). In (49), the verb, also a nominal/adjectival form, is suffixed with $-v$ - directly followed by gender number agreement, and the auxiliary, with an optative meaning ("want"). In all these series, the agent can take the $-e$ form (ergative), with transitive predicates, or the dative postposition with intransitive:

Sitā.e kāgal vac.yo
Sita.F.SG.ERG letter.M.SG
'Sita read the letter.' (Mistry 1997)

(GUJARATI)

'Sita read the letter.' (Mistry 1997)

(48) a. mar.e caupd̄̄ vanc.v.a.n.ī che / lekh lakh.vano che 1S.FG.AG book.F.SG read.van.F.SG be.PRS.3 article.M.SG write.van.M.SG be PRS.3S 'I have to read a book

/ to write an article'

(48) b. tamne kyā javanu che

2.DAT where go.INF.N PRS.3 SG

'Where do you have to go?' (Cardona \& Suthar 2003)

a. mar.e caupdī vanc.v.iche

lekh

lakh.vo

che

1SG.AG book.F.SG read.v.F.SG be.PRS.3 article.M.SG write.v.M.SG be.PRS.3SG

'I want to read a book'

(49) b tam ne kyā ja.v.u che

2 DAT where go.INF.N be.PRS.3

'Where do you want to go?' (Cardona \& Suthar 2003)

(49) c. mār.e gujrātī bhāșā bol.v.ī che

1SG.ERG Gujarati language.F.SG speak.v.F.SG be.PRS.3SG

'I want to speak Gujarati'

The reason why a "be" auxiliary is required to provide in Gujarati for approximately the same modal meanings as expressed by the main verb itself in Marathi, is clearly explained by Chatterji (1926: 966). He derives the Gujarati verbal noun karv $\tilde{\bar{u}}$ from the verbal adjective (passive obligative participle) kartavyam and its enlarged form *kartavyakam. The Sanskrit form, endowed with a "vague mandatory sense, with an express future implication", evolved in two directions in NIA: "the simple future notion evolved gradually" and is found mainly in Eastern languages today, while "side by side with it, the old notion of an action which is to be done continued, and was modified into simply the notion of an act". Marathi maintained the 
suffix in its subjunctive form $-\bar{a} v$ - (maya $u t h \bar{a} v l a$ "I.INS. should rise") with the strong meaning of the "action to be done", whereas Gujarati retained the weaker meaning of the "simple notion of an act" in the form of the verbal noun.

The same form (short form, only involving $-v$ - after the verb root and before agreement) also occurs with other auxiliaries, like joy for necessity, with both dative and ergative case markers for the agent:

(50) mār.e /ma.ne ghar ja.v. $\tilde{\bar{u}}$ joi.e

1SG.ERG/1SG.DAT home go.v.N be.necessary.PRS.3SG

'I should /have to go home'

\subsection{With predicates unrelated to the old-tavya passive participle}

The HU verbal noun in $-n \bar{a}$ behaves in obligative clauses like the Gujarati - $v$ - verbal adjective (agreement with the patient or in the masculine singular if the main verb is intransitive) but requires the dative of the logical subject, with no possible alternation with the ergative case.

(51) a. mujhko jūte kharìdne haĩl parẽge

1SG.DAT shoe.M.PL buy.INF.M.PL be.PRS.M.PL fall.FUT.M.PL

'I must / will have to buy shoes'

(51) b. muhjko jānā hai

1SG.DAT go.INF.M.SG be.PRS.3SG 'I have to go'

This is the alignment which is also required for experiential clauses, with dative subject (perceiver, human target) and intransitive verb agreeing with the stimulus in the nominative case, the reason why obligative clauses such as (51) are usually considered as a sub-category of the experiential clauses like (52):

(52) a. mujhko choțe choțe ghar dikh rahe the

1SG.DAT small.M.PL small.M.PL house.M.PL appear PROG.M.PL be.PST.M.PL

'I saw (could see) small houses'

(52) b. mujhko thand hai

1SG.DAT cold.F.SG be.PRS.3SG

'I am cold'

The verbal noun is not derived from the -tavyam nominal form of Sanskrit, but the intuition of Chatterji regarding the meaning of the IA verbal noun helps to understand the structural, if not morphological, analogies between the obligative pattern in (51) and the modal patterns of Gujarati and Marathi, which have retained the $-v$ - morphology.

Not surprisingly, certain languages or dialect variants allow the same case alternations as observed in Gujarati or Marathi. Such is the case in Garhwali (53a) and Kumaoni (53b), two Himalayan languages, in the obligative clauses corresponding to Hindi $(52 \mathrm{c})^{23}$ :

(53) a. maĩna / maĩla

(53) b. maĩle 1SG.ERG

c. mujhko
1SG.DAT

$\begin{array}{llll}\bar{a} j & \text { barat rakhṇa } & & \text { (GARHWALI) } \\ \bar{a} j & \text { barat rakhṇa } & \text { (KUMAONI) } \\ \text { today } & \text { fast keep.INF } & \text { "I have to fast today" } \\ \bar{a} j & \text { vrat rakhna } & \text { hai } & \text { (HINDI) } \\ \text { today } & \text { fast } & \text { keep.INF } & \text { be.3SG }\end{array}$

\footnotetext{
${ }^{23}$ Whereas Nepali also displays an alternation from ergative le, dative lai and nominative (Masica 1990) and Kumaoni seems to be now shifting from ergative to dative (Kryzstof.Stronski's personal communication).
} 
Whereas MSH rules out case alternations in obligative clauses $(53 \mathrm{c}, 51)$, non standard Hindi allows them, particularly Delhi Hindi (54a), which is supposedly influenced by Punjabi (and Western speeches such as Haryanvi or Bangaru). The morphological closeness of the Punjabi dative/accusative marker (n $\tilde{\bar{u}})$ with the Hindi ergative marker $(n e)$, besides, etymologically cognate as seen above, is certainly largely responsible for the present currency of the expression:

(54) a maĩne jānā hai

(54) b mujhko jānā hai

1SG.DAT go.INF be.3SG

Whatever the semantic differences (discussed in Bashir 1999), varying with speaker groups, what is important for the discussion here is the consistency of the alternations of dative and ergative throughout Indo-Aryan for modalities.

\section{Conclusion}

As seen in the last sections, there are structural and sometimes semantic affinities between ergative and dative alignments. These have been first accounted for by Delancey (1981): aspectual semantics require the linguistic viewpoint to be associated with the result (goal) and not with the source at the "natural" origin of the process, which is encountered secondarily (hence marked), upstream so to speak. Similarly, in experiential statements with a "dative subject", the stimulus is the source of the linguistic viewpoint and the experiencer is encountered upstream. In this logic, the source no longer retains the same relation with the process and its goal than in transitive constructions. In the transitive model, typically correlated to the action sentence, the source is the natural start-point of a process ending on the goal (endpoint), whereas in the ergative model the source is outside the predication, which has the goal as its start-point - something that Benveniste captured in a different way when analysing the perfect as "possessive", that is to say, not involving a source oriented action, but locating a state predication vis-à-vis an actor.

According to these views, which involve psychological and cognitive considerations, the ergative case is not a simple grammatical marker used to reverse the same trajectory, within the same cognitive scenario, as in the transitive pattern. As Langacker (1999: 35) puts it, the trajectory itself maps a different cognitive scenario, and ERG encodes an altogether different relation, involving a different perception, thus being rather a semantically significant case and "only incidentally associated strategy with grammatical relations". It only profiles the last part of the clause as "onstage" (the "trajector" and main figure being the patient), in an autonomous way (not dependant on the source), whereas a nominative transitive alignment profiles the full path (the "trajector" and main figure being the agent) and maps the relation as dependant on the source. The ergative model is then more like an intransitive structure, a thematic relation ("[Bob] ice melted"). As such, "it enjoys a certain autonomy vis-à-vis the agent and the flow of energy, even for inherently energetic processes", like an "absolute construal". The starting point has conceptual autonomy from the source, a reason why "the path involved is more abstract and of lesser cognitive salience". Both structures are then shown to differ deeply, and not only at the morphological level. Such a view is certainly a radical formulation, and it certainly goes against the conscious "linguistic perception" of the present Indo-Aryan speakers, for whom the agent is perceived as a subject and not as a localizer. Yet the fact that the ergative marker is also present in modal - transitive or 
intransitive - statements in a number of Indo-Aryan languages argues in favour of taking such hypotheses seriously.

Abreviations not in the Leipzig gloss: PPP: passive past participle, OVA: obligative verbal adjective; SK: Sanskrit, PRK: Prakrit

\section{References}

Bashir, Elena. 2006. The Urdu and Hindi Ergative Postposition ne: its Changing Role in the Grammar. The Year book of South Asian Languages and Linguistics. Rajendra Singh (ed.), 11-36. Amsterdam: De Gruyter/Mouton.

Beames, John. 1970 [1871]. A Comparative Grammar of the Modern Aryan Languages of India. Delhi: Munshiram Manoharlal.

Benveniste, Emile. 1966 [1952, 1960, 1965]. Problèmes de linguistique générale. Paris : Gallimard.

Bloch, Jules. 1970 [1920]. The Formation of the Marathi Language. Delhi: Motilal Banarsidass.

Bloch, Jules. 1906. La Phrase nominale en sanscrit. Paris: Champion.

Breunis, André. 1990. The Nominal Sentence in Sanskrit and Middle Indo-Aryan. Leiden: Brill.

Bubenik, Vit. \& Ch. Paranjape. 1996. Development of Pronominal Systems from Apabhramsha to New Indo-Aryan. Indo-Iranian Journal 39: 11-32.

Bybee, Joan., R.D. Perkins \& W. Pagliuca (eds.). 1994. The Evolution of Grammar, Tense, Aspect and Modality in the Languages of the World. Chicago-London: Chicago Univ.Pr.

Cardona, George. 1970. The Indo-Iranian Construction mana/mama krtam. Language 46:1-12. Cardona, George. \& B. Suthar. 2003. Gujarati. In The Indo-Aryan Languages. In Cardona, G. \& D. Jain (eds.), 658-97. London: Routledge (658-97).

Chatak, Govind. 1966. Madhyapahari ka bhashashastrîa adhyayan. Delhi: Radhakrishna Pr. Chatterji, Sunita Kumar. 1986 [1926]. The Evolution of Bengali Language. Delhi: Rupa. DeLancey, Scott. 1981. An interpretation of split ergativity and related patterns. Language 57-3: 626-57.

Desai, Mohan. 1926. Jain Gurjar Kavyo (3 vol.). Bombay: Jain Svetambar Conference Office. Davison, Alice. 2002. Agreement features and projections of Tense and Aspect, in The Yearbook of South Asian Languages and Linguistics Rajendra Singh (ed.), 27-57. Delhi: Sage. Dixon, R.M.W. 1994, Ergativity. Cambridge: Cambridge University Press.

Falk, Yehuda N. 2006. Subject and Universal Grammar. Cambridge: Cambridge University Press.

Grierson, George A. 1903-28. Linguistic Survey of India. Delhi: Motilal Banarsidass. Hock, Hans Heinrich. 1992. Studies in Sanskrit Syntax. Delhi: Motilal Banarsidass.

Jha, Subhadra.1985 [1958]. The Formation of the Maithili Language. Delhi: Munshiram Manoharlal.

Juyal, Govind. 1976. Madhya Pahari Bhasha (Garhvali Kumaoni) ka anushilan aur uska hindi se sambandh. Lucknow: Navyug Granthagar.

Kachru, Yamuna. 1987. Ergativity, Subjecthood and Topicality. Lingua 71: 223-38.

Kellogg, Rev. S. H. 1972 [1875]. A Grammar of the Hindi Language [... Braj, (...) dialects of Marwar, Kumaon, Awadh, Baghelkhand, Bhojpur, etc.]. Delhi: Oriental Book Reprints.

Kuryłowicz, Jerzy. 1960 [1953, 1931]. Esquisses Linguistiques, Kraków: Polska Akademia Nauk.

Kuryłowicz, Jerzy. 1965. The Evolution of Grammatical Categories. Diogène 51: 51-71. 
Langacker, Ronald. 1999. Grammar and conceptualization. Berlin-New-York: Mouton De Gruyter.

Mahajan, Anup. 1997. Universal Grammar and the Typology of Ergative Languages. In Studies on Universal Grammar and Typological Variation. A. Alexiadou \& T. A. Hall (eds), 35-57. Amsterdam: Benjamins.

Masica, Colin. 1990. The Indo-Aryan Languages. Cambridge: Cambridge University Press.

Mistry, P. J. 1997. Objecthood and specificity in Gujarati. In The Life of Language, J. Hill, P. J. Mistry and L. Campbell (eds.), 425-442. Berlin: Mouton de Gruyter.

Montaut, Annie. 1996. L'évolution des systèmes perfectal et futur en indo-aryen occidental et oriental. Journal Asiatique 284.2 : 325-360.

Montaut, Annie. 1999. Le Renouvellement des formes verbales en hindi / ourdou. Journal Asiatique 287.2 : 587-628.

Montaut, Annie. 2004. Oblique main arguments in Hindi as localizing predications. In Non nominative Subjects. Bhaskararao \& Subbarao (eds.)35-56. Amsterdam: Benjamins.

Montaut, Annie. 2007. The evolution of the tense-aspect system in Hindi/Urdu: the status of the ergative alignment. Proceedings of the LFG06 Conference (M. Butt and T. Holloway King (eds.), CSLI Publications.

Nespital, Helmut. 1986. Zum Verhältnis von Genus Verbi, Nominativ- und ErgativKonstruktionen im Hindoarischen aus synchroner und diachroner Sicht. Müinchener Studien zur Spachwissenschaft 47: 127-58.

Peterson, John. 1998. Grammatical relations in Päli and the emergence of ergativity in IndoAryan. München: Lincom Europa.

Pirejko, L.A. 1979. On The Genesis of Ergative Construction in Indo-Iranian. In Ergativity; Towards a Theory of Grammatical Relations. Franz Plank (ed.), 658-97. London: Academic Press (658-97)

Saxena, Ram Baburam. 1971 [1937]. Evolution of Awadhi. Delhi: Motilal Banarsidass. Speijer, Jan S., 1980 [1886]. Sanskrit Grammar. Delhi: Motilal Banarsidass.

Strnad, Jaroslav. 2012. A note on the Locative/Instrumental/Ergative in Old Hindi. Archiv Orientalni 30 (41-64).

Stronksi, Kryzstof. 2010. Non-nominative Subjects in Rajasthani and Central Pahari. The Status of the Ergative and Obligative Constructions. Lingua Posnaniensis LII-1: 81-97. Tagare, G.V. 1948. Historical Grammar of Apabhramsha. Poona: Deccan College.

Tessitori, Luigi. 1913. On the origin of Dative and Genitive postpositions in Marwari and Gujarati. Journal of the Royal Asiatic Society 45-3: 553-67.

Tessitori Luigi. 1914-16. Notes on the Grammar of the Old Western Rajasthani, with Special Reference to Apabhramsha and to Gujarati and Marwari. Indian Antiquary 43-44: 1-106.

Tessitori, Luigi. 1914. On the Origin of the Perfect Participles in 1 in the Neo-Indian Vernaculars. Zeitschrift der Deutschen Morgenländischen Gesellschaft 68: 571-8.

Tiwari, Udayan N. 1966. The Development of Bhojpuri. Calcutta: The Asiatic Society vol. X. Tiwari, Udayan N. 1961. Hindi Bhasha ka udgam aur uska vikas. Prayag: Bharati Bhandar. Trask, R. L. 1979. On the Origins of Ergativity. In Plank, F. (385-404).

Trumpp, E. 1872. Grammar of the Sindhi Language. London-Leipzig.

Wali, Kashi. 2004a. Marathi. Munchen: Lincom-Europa, Languages of the World/Materials. Wali, Kashi. 2004b. Non-nominative Subjects in Marathi. In Non nominative Subjects (eds. Bhaskararao \& Subbarao). Amsterdam: Benjamins (223-52).

[Benveniste, E. 1966-1974: Problems in general linguistics, translated by Mary Elizabeth Meek, 2 vols. Coral Gables, Florida: University of Miami, P 1971. ISBN 0-87024-132-X]

To be added or omitted according to the precision needed by the publisher: 
Details for Kurylowicz: ([1953]. Aspect et Temps dans l'histoire du persan : 109-118, [1931]. Les Temps composés du roman : 104-108).

Details for Benveniste : ([1952]. La construction passive du parfait transitif. Vol.1:176-86, [1960]. Etre et avoir dans leurs fonctions linguistiques. Vol.1:187-207, [1965]. Les transformations des catégories grammaticales. Vol. 2:127-136) 